\title{
巨椋池・横大路沼干拓地の表層土壌中における 水生植物散布体の残存状況とその鉛直分布
}

Persistence and Vertical Distribution of Diaspores of Aquatic Plants in the Surface Soil Layer of Oguraike and Yokoojinuma Drained Lands

松本 仁 ${ }^{*}$ 今西亜友美 ${ }^{*}$ 今西 純一** 森本 幸裕 ${ }^{* *}$ 夏原 由博**
Hitoshi MATSUMOTO Ayumi IMANISHI Junichi IMANISHI
Yukihiro MORIMOTO Yosihiro NATUHARA

\begin{abstract}
The nature restoration of wetlands is strongly required as they have been severely altered. We focused on the drained lands, widely spread in the 20th century. It is important to study the diaspores of aquatic plants in the soil to grasp the regeneration potential of the drained lands. The purpose of this study was to reveal the vertical distribution of diaspores of aquatic plants in the soil of Oguraike and Yokoojinuma drained lands, where more than 50 years passed after the reclamation. The soil cores with the length of $50 \mathrm{~cm}$ were collected from nine locations. The cores were cut into five sections and studied on the germination ability of the diaspores in the soil under $0-\mathrm{cm}$ and $5-\mathrm{cm}$ depth of water. As a result, we found that the number of species and individuals exponentially decreased when depth of soil sampling became greater. Six endangered plant species were germinated in the experiment and the two among them were the species that could not be found on site at the locations of soil core samplings.
\end{abstract}

Keywords: aquatic plant, diaspore, drained land, emergence method, endangered species キーワード：水生植物，散布体，干拓地，撒き出し実験，絶滅危惧種

\section{1.はじめに}

干拓事業は，水田拡張，食糧増産を目的として積極的に推進さ れてきた ${ }^{1}$ 。一方で，豊かな湿地の生態系が失われたという側面 もある。近年, 早崎内湖 $(1963-1970 \text { 年干拓 })^{2)}$, 河北潟 $(1963-$ 1970 年干拓 $)^{3)}$ や手賀沼 (1958-1965 年干拓 $)^{4)}$ などでは, 湿地植 物の復元を目指した干拓地の自然再生が試みられている。

植生の復元には, 根株移植, 種子播種, 表土撒き出しなどの方 法があるが，生物学的侵入や遺伝的擋乱を防止するために, 自然 再生を行う現場かその付近の郷土種を用いることが望ましい ${ }^{5)}$ 。

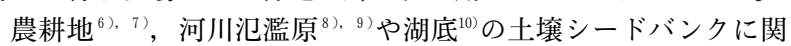
しては多くの研究がある。しかし，干拓地における散布体バンク に関する研究は少ない。百原ら ${ }^{4}$ は, 約 40 年前に干拓された場 所において，発芽試験によりセンニンモが発芽することを見出し， 堆積物中の土袞シードバンクが自然再生に利用可能であることを 示した。また, 1963 年から 1970 年に干拓が完了した早崎内湖で は土袞シードバンクを用いた自然再生事業が行われているが，干 拓が行われたのは比較的新しい2)。

干拓地の土層は, 干拓前に成立していた植生の散布体を含みな がら堆積したものである ${ }^{11}$ 。また, 埋土種子は, 時間の経過とと もに発芽力が低下する。これまでに埋土種子を連続的に鉛直分布 を調べた研究には三角州の湿地で $14 \mathrm{~cm}$ 深さまでの土層を 9 層 に分割し撒き出し試験を行った研究 ${ }^{11}$, 淡水の湿地で $10 \mathrm{~cm}$ の深さ までの土層を 2 層に分割して撒き出し試験を行った研究12)等があ る。しかし, 干拓地においてさらに深い部分の土㗒の連続的な鉛 直分布は研究されていない。散布体バンクの鉛直方向の分布を調 べることにより，絶滅危惧種や外来種の分布を知ることができ，

干拓地の自然再生を行う上での土層の選定に有用な情報が得られ ると考えた。

本研究は, 干拓後 50 年以上が経過した干拓地における水生植 物の散布体の鉛直方向の分布と, 散布体バンクの有効性を明らか にすることを目的とした。

\section{2. 方法}

\section{（1）調查対象地}

京都府京都市伏見区, 宇治市, 久御山町の巨椋池干拓地之, 京 都市伏見区の横大路沼干拓地を調査対象地として選定した。調査 対象地は，桂川，宇治川，木津川が合流する三川合流地点の北東 約 $6 \mathrm{~km}$ の場所である。巨椋池は, 1933 年（昭和 8 年）から 1941 年（昭和 16 年）にかけて国営第 1 号の干拓事業として干拓 された ${ }^{13)}$ 。横大路沼は 1954 年（昭和 29 年）に干拓された ${ }^{14}$ 。

巨椋池とその周辺の湿地は, 干拓前は豊かなフロラで知られて おり，三未 ${ }^{15}$ による水生植物フロラの調查では，47 科 96 属 153 種 3 変種が記録された。この属数は, 日本産の水生植物の 8 割強 を占めた。巨椋池干拓地と周辺低湿地は, 近畿圈の都市環境イン フラのグランドデザイン ${ }^{16}$ において，水と緑のネットワークの重 点拠点に位置づけられ，湿地環境の保全・再生が望まれている。

\section{(2) 土壤の採集}

干拓前の池あるいは沼における位置，干拓後の土地利用を考慮 し, 巨椋池干拓地にて 5 ヶ所, 横大路沼干拓地にて 4 ヶ所の調查 地点を選定した（図一 1 ，表一 1 ）。

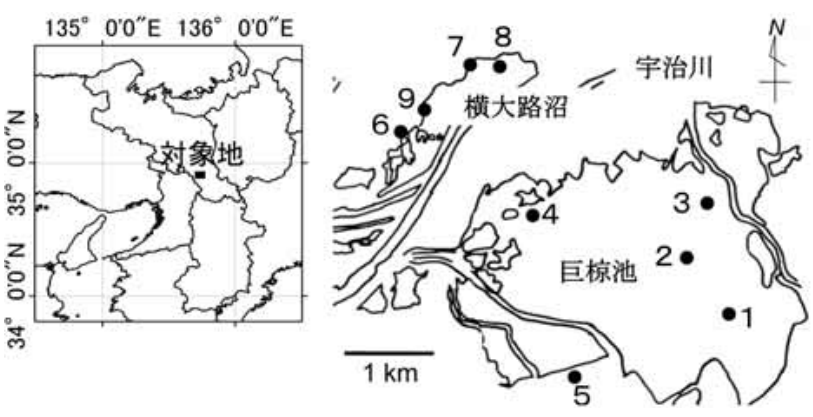

図-1 調査地点の位置

（詳細図の輪郭線は明治 42 年正式二万分の一地形図をもとに描いた）

*京都大学大学院地球環境学舎 **京都大学大学院地球環境学堂 
表 -1 調査地点

\begin{tabular}{|c|c|c|c|c|}
\hline & 地点No. & $\begin{array}{c}\text { 干拓前の池·沼におけ } \\
\text { る位置 }\end{array}$ & $\begin{array}{c}\text { 土袞採集時点までの土地 } \\
\text { 利用 }\end{array}$ & 優占種 \\
\hline \multirow{5}{*}{ 巨椋池 } & 1 & $\begin{array}{l}\text { 池の周辺部から最深部 } \\
\text { への移行部分 }\end{array}$ & 水田として利用 & - \\
\hline & 2 & 池の最深部付近 & 近年は休耕田として放置 & セ侈アワダチリウ \\
\hline & 3 & 池の周縁水域 & 永田として利用 & \\
\hline & 4 & 池の周縁水域 & 畑として利用 & - \\
\hline & 5 & 池と陸の移行部 & 水田として利用 & - \\
\hline \multirow{3}{*}{ 横大路沼 } & 6 & 沼の周 & $\begin{array}{l}\text { 土地区画整理事業で擋 } \\
\text { 乱された地地 }\end{array}$ & - \\
\hline & 7 & 沼の屋 & 畑地の横の水路 & - \\
\hline & $\begin{array}{l}8 \\
9\end{array}$ & $\begin{array}{l}\text { 沼の最深部付近 } \\
\text { 沼の周縁水域 }\end{array}$ & $\begin{array}{l}\text { 放棄田であり樹林化 } \\
\text { 近罗 }\end{array}$ & 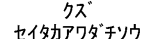 \\
\hline
\end{tabular}

土壌の採集は，2007 年 3 月から 4 月にかけて実施した。ハン ドオーガー（穴径 $\phi 3 \mathrm{~cm}$ ）により, 地表面から深さ $50 \mathrm{~cm}$ までの 土壌コアを 1 調査地点あたり 5 本採集した。 4 本は土壌の撒き出 し実験に，1 本は土袞断面の観察と放射性炭素による土壌の年代 測定に用いた。客土の有無については, 近畿農政局職員から, 現
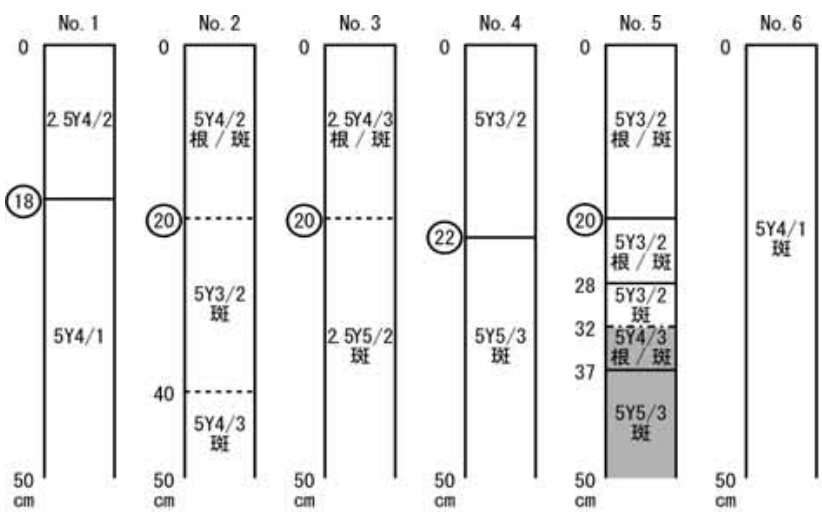

アルファベットを含む数字は、修正マンセル表色系の 色相 明度/彩度を示す。 「根」は根が誰察されたことを、「斑」は斑鉄が钼察されたことを示す。 ○は鎯床層の深さ $(\mathrm{cm})$ を示す。

図一 2 土袞断面の観察

表－2＼cjkstart撒き出し実験により発芽した種

\begin{tabular}{|c|c|c|c|c|c|c|c|c|c|c|c|}
\hline \multirow{2}{*}{ 和名 } & \multirow{2}{*}{ 学名 } & \multirow{2}{*}{$\begin{array}{l}\text { 水生 } \\
\text { 植物 }\end{array}$} & \multirow{2}{*}{\multicolumn{3}{|c|}{ 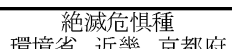 }} & \multirow{2}{*}{$\begin{array}{c}\text { 外来 } \\
\text { 種 }\end{array}$} & \multirow{2}{*}{$\begin{array}{c}\text { 三木 } \\
(1927)\end{array}$} & \multirow{2}{*}{$\begin{array}{c}\text { 坂東 } \\
(2001)\end{array}$} & \multirow{2}{*}{$\begin{array}{l}\text { 現地 } \\
\text { フロラ }\end{array}$} & \multicolumn{2}{|c|}{ 湛水条件 } \\
\hline & & & & & & & & & & $0 \mathrm{~cm}$ & $5 \mathrm{~cm}$ \\
\hline シャジクモ & Chara braunii & 0 & VU & & & & $\mathrm{O}$ & 0 & & 4 & 14 \\
\hline ジュズフラスコモ & Nitella axillaris & 0 & CE & & & & & & & 0 & 3 \\
\hline ミズワラビ & Ceratopteris thalictroides & 0 & & 準 & 要 & & 0 & 0 & 0 & 21 & 0 \\
\hline トキンソウ & Centipeda minima & & & & & & 0 & $\bigcirc$ & $\bigcirc$ & 35 & 1 \\
\hline タカサブロウ & Eclipta prostrata & 0 & & & & & & 0 & 0 & 7 & 0 \\
\hline アメリカアゼナ & Lindernia dubia & & & & & 0 & & & 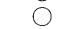 & 3 & 1 \\
\hline アゼナ & Lindernia procumbens & & & & & & 0 & 0 & 0 & 205 & 57 \\
\hline トキワハゼ & Mazus pumilus & & & & & & & 0 & 0 & 9 & 0 \\
\hline ムシクサ & Veronica peregrina & & & & & & & 0 & 0 & 2 & 0 \\
\hline カワヂシャ & Veronica undulata & & & 準 & & & 0 & & & 4 & 0 \\
\hline & Oenanthe javanica & 0 & & & & & 0 & 0 & 0 & 2 & 0 \\
\hline アメリカミズキンバイ & Ludwigia decurrens & 0 & & & & 0 & & 0 & 0 & 32 & 0 \\
\hline チョウジタデ & Ludwigia epilobioides & 0 & & & & & 0 & 0 & 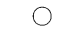 & 16 & 2 \\
\hline ホソバヒメミソハギ & Ammannia coccinea & & & & & 0 & & & 0 & 6 & 4 \\
\hline キカシグサ & Rotala idica var. ulgrinosa & 0 & & & & & 0 & 0 & & 2 & 15 \\
\hline ミズマツバ & Rotala pusilla & 0 & $\mathrm{VU}$ & $\mathrm{C}$ & 危惧 & & 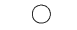 & 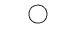 & 0 & 4 & 2 \\
\hline タネツケバナ & Cardamine flexuosa & & & & & & 0 & 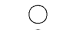 & $\checkmark$ & 26 & 0 \\
\hline ノミノフスマ & Stellaria alsine var. undulata & & & & & & & 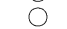 & 0 & 8 & 0 \\
\hline スベリヒュ & Portulaca oleracea & & & & & & & 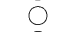 & 0 & 2 & 0 \\
\hline イヌタデ & Polygonum longisetum & & & & & & & & 0 & 2 & 0 \\
\hline コウガイゼキショウ & Juncus leschenaultii & 0 & & & & & & 0 & 0 & 0 & 1 \\
\hline ミズアオイ & Monochoria korsakowii & 0 & NT & A & 寸前 & & 0 & & & 1 & 1 \\
\hline コナギ & Monochoria vaginalis & O & & & & & & 0 & 0 & 2 & 3 \\
\hline アオウキクサ & Lemna paucicostata & c & & & & & & & 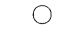 & 5 & 2 \\
\hline タマガヤツリ & Cyperus glomeratus & 0 & & & & & 0 & 9 & s & 13 & 3 \\
\hline コゴメガヤツリ & Cyperus iria & & & & & & & & & 5 & 0 \\
\hline ヒデリコ & Fimbristylis miliacea & 0 & & & & & 0 & 0 & 0 & 204 & 6 \\
\hline ホタルイ & Scirpus juncoides var. hotarui & 0 & & & & & 0 & 0 & 0 & 1 & 2 \\
\hline メヒシバ & Digitaria abscendens & & & & & & & & & 3 & 0 \\
\hline イヌビエ & Echinochloa crus-galli & 0 & & & & & 0 & 0 & 0 & 4 & 2 \\
\hline ケイヌビエ & Echinochloa crus-galli var. caudata & 0 & & & & & & 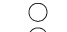 & 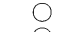 & 4 & 1 \\
\hline ニワホコリ & Eragrostis multicaulis & & & & & & & & & 12 & 0 \\
\hline アゼガヤ & Leptochloa chinensis & 0 & & & & & 0 & 0 & & 7 & 2 \\
\hline スズメノカタビラ & Poa annua & & & & & & & 0 & ○ & 1 & 0 \\
\hline イチコツナキ & Poa sphondylodes & & & & & & & & & 1 & 0 \\
\hline
\end{tabular}

「メ」は三木(1927)において属レベルまでしか同定されていないことを示す。

湛水条件の列の数値は, 発芽個体数 $/ 156 \mathrm{~cm}^{2}$ 表表。

※括弧内柆本表にお计万略号老示寸

環境省 RDB：絶滅危惧I類 (CE), 絶滅危惧 I A 類 $(C R)$, 絶滅危惧 IB類 (EN), 絶滅危惧 II 類 (VU), 淮絶滅危惧 (NT)

近畿RDB: 絶滅危惧種A (A), 絶滅危惧種B (B), 絶滅危惧種 (C), 準絶滅危惧種 (準)

京都府RDB: 絶滅寸前種 (寸前), 絶滅色惧種(危惧), 準絶滅危惧種 (準), 要注目種(要)
在の巨椋池干拓地の地形データから巨椋池の地形は基本的に改変 されていないこと，また，調査地点 3 において，干拓前の巨椋池 と横大路沼を知る 80 歳代の土地所有者から, 畑地以外は客土は 行われていないことを聞きとった。

\section{(3) 土袞撒き出し実験}

プラスチック容器（底面積約 $78 \mathrm{~cm}^{2}$ ) に，2 $\mathrm{cm}$ の厚みで高熱処 理済みの砂を入れ，その上に $10 \mathrm{~cm}$ 毎に切り分けた土㙵コアを置 き, ヘラを用いて平らにならした。本研究においては，水生植物 を対象としたので，湛水条件として $0 \mathrm{~cm}$ 区と $5 \mathrm{~cm}$ 区の 2 水準を設 定し，それぞれの条件にて各 2 サンプルで実験を行った。また，

種子を含まない水生植物栽培用土㙵を用いて対照区を同様に設定 した。容器は, 京都大学フィールド科学教育研究センター北白川 試験地（京都市左京区）のビニールハウス内にランダムに配置し, 2007 年 4 月から 12 月にかけて, 発芽した植物の種名と個体数を

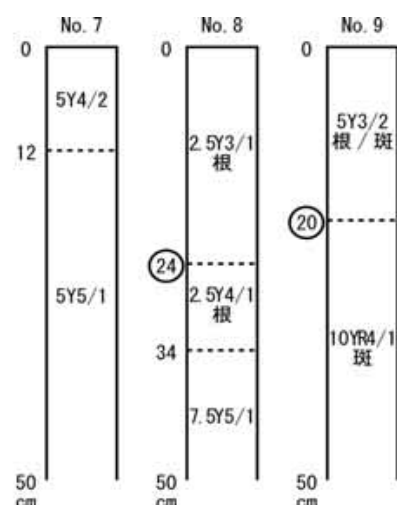

記録した。発芽した植物は種子散 布前に同定し抜き取った。種子散 布前の同定が困難なものについて は，別容器に移植栽培後，同定し

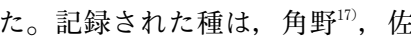
竹ら ${ }^{18) ~ 20)}$ および清水 ${ }^{21)}$ を用いて, 湿地に生育すると記載されている 種を水生植物として区分した。絶 滅危惧種は，環境省 ${ }^{22}$ ，近畿 ${ }^{23}$ お よび京都府 ${ }^{24)}$ のレッドデータブッ クに記載されている種であるかど うかを調べた。分析は各 2 サンプ ルのデー夕を合わせて行った。

\section{(4) 現地フロラ調査}

各調査地点に扔いて，ボーリン グを行った地点から半径 $5 \mathrm{~m}$ 以内 を調査区域とし生育する 植物の種を記録した。調 查は, 2007 年 7 月, 2007 年 9 月および 2008 年 5 月に実施した。

\section{（5）土壤の年代測定}

巨椋池干拓地（調査地 点No. 2 ）および横大路 沼干拓地（調査地点 No. 6 ）の深さ $50 \mathrm{~cm}$ の土袞 堆積物の年代を, 放射性 炭素年代測定（AMS 測 定）により測定した。

\section{3. 結果}

\section{（1）調査地点の土㙵}

各調查地点の地表面か ら深さ $50 \mathrm{~cm}$ までの土壌 は，基本的には粘土質で あった（図ー2）。また， No. 6 と No. 7 を除く調 查地点において鋤床層が 観察された。鋤床層とは， 水田の作土層の湛水後の 代かきによる土粒子分散 と緻密化により形成され る土層である ${ }^{25)}$ 。No. 5 と No. 8 では, 鋤床層 

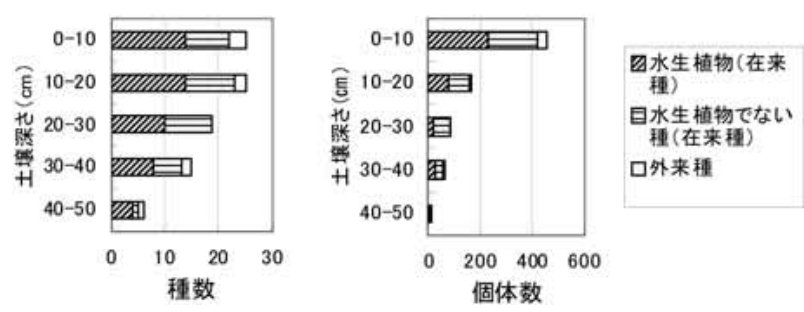

図－3土壤深さと発芽した種数あるいは個体数の関係

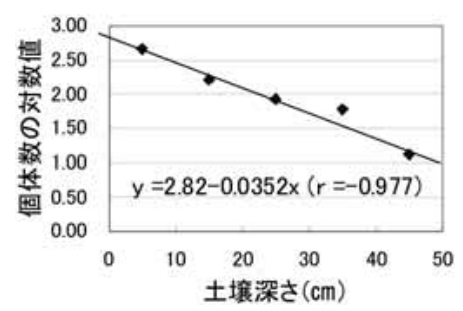

図- 5 発芽個体数（底を 10 とす る対数值) と土壌深さの 関係
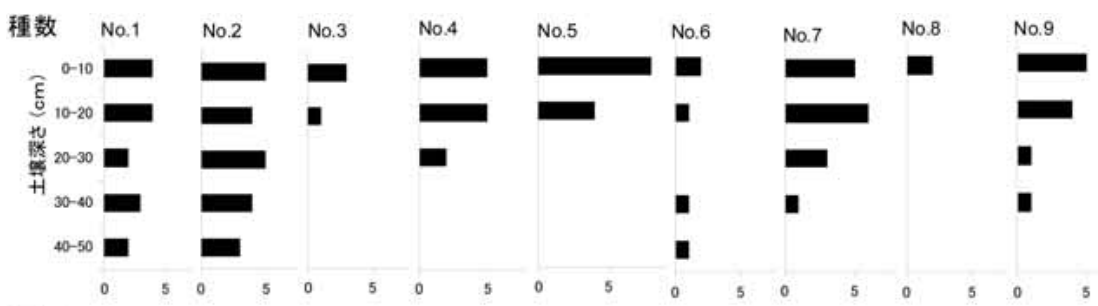

個体数 No.1 No.2

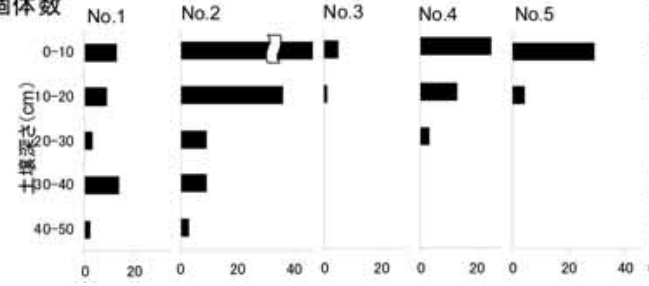

図-
より下部にも根の侵入が観察された。

\section{(2) 土袞撒き出し実験}

車軸藻植物 2 種, シ夕゙植物 1 種, 被子植物 32 種, 計 775 個体 の発芽があった（表一 2)。その内, 水生植物は 19 種 388 個体の 発芽があった。外来種は, アメリカアゼナ, アメリカミズキンバ イ, ホソバヒメミソハギの 3 種が記録された。また, 絶滅危惧種 は, シャジクモ, ジュズフラスコモ, ミズワラビ, カワヂシャ, ミズマツバ，ミズアオイの 6 種が記録された。

(i) 土袞深さについて

土壌の深さが増すほど, 水生植物の種数と個体数が減少すると いう傾向が見られた（図 -3 )。 0 〜 $10 \mathrm{~cm}$ と $10 \sim 20 \mathrm{~cm}$ の土層の比 較を行うと, 個体数は著しく減少するのに対し, 種数には違いが 見られなかった（図一 3 )。また，鋤床層のある調查地点（No. $1 \sim$ No. 5 , No. 8, No. 9 ) であっても, 土㙵深さ $50 \mathrm{~cm}$ まで水 生植物の発芽が記録された（図-4)。外来種は, $20 〜 30 \mathrm{~cm}$ の土 層をのぞくすべての土層において発芽した（図－3）。在来種に おいて水生植物之水生植物でない種の間に, 違いは見出せなかっ た（図-3)。図- 5 に撒き出し試験により得られた個体数と土

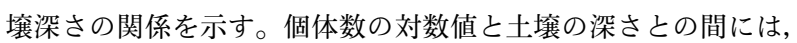
強い負の相関が認められた（回帰係数 $\mathrm{r}=-0.977 ） 。$

絶滅危惧種のうち, ミズワラビとミズマツバは, 表層に近い土 堙深さから多く発芽する傾向があった（図－6）。一方, シャジ クモおよびジュズフラスコモは，土壌深さ $40 \sim 50 \mathrm{~cm}$ にいても 発芽が記録された（図一 6 )。ミズアオイは調査地点No. 7 にお いて 10〜20，20３0cmの土壌深さにおいて 1 個体ずつが発芽し た。

外来種については, アメリカミズキンバイは, 表層に近い土堙 で最も多く発芽するものの深部まで発芽し, ホソバヒメミソハギ は，表層付近のみから発芽が見られた（図一 6 )。

調査地点 No. 2 および No. 6 の深さ $50 \mathrm{~cm}$ の土㙵堆積物の年代 は，それぞれ $560 \pm 30$ 年, $930 \pm 30$ 年であった。

(ii) 湛水条件について

$0 \mathrm{~cm}$ 区 $5 \mathrm{~cm}$ 区では，それぞ れ 33 種 653 個体と 19 種 122 個 体の発芽があり, その内, 水生 植物は 17 種 329 個体, 15 種 59 個体であった（表一 2 )。 $0 \mathrm{~cm}$ 区の方が種数, 個体数ともに多 くの発芽が見られた。シャジク モ, ジュズフラスコモ, キカシ グサ, コナギ，ホタルイの 5 種 は, $5 \mathrm{~cm}$ 区の方が $0 \mathrm{~cm}$ 区よりも発芽数が 多かった（表一2）。種により，発芽に 適した湛水深さが異なる傾向が見られた (表一 2 , 図-6)。

(iii) 調查地点について

全体に巨椋池干拓地の方が横大路沼干 拓地よりも種数や固体数が多い傾向が見 られた (図-7) が, Mann-Whitney U 検定では有意な差はなかった（それぞれ $\mathrm{p}=0.137, \mathrm{p}=0.085)$ 。また, 調查地点に おける干拓前の池・沼における位置や土 培採集時点までの土地利用之, 水生植物 の種数および個体数との関係を検討した が，明確な関係は見られなかった。

(iv）干拓前および現在のフロラとの比較 三木 ${ }^{15)}$ で記録された 153 種のうち 11 種の水生植物が土壌撒き出し実験により 発芽した。ミズアオイは三木 ${ }^{15)}$ に記録されているが, 坂東 ${ }^{26)}$ や今 回の現地調查では生育が記録されなかった。また，ジュズフラス コモは三木备)において種としては確認されておらず（Nitella sp. の記録はある), 坂東 ${ }^{26)}$ や今回の現地調査でも生育の記録はなかっ た。しかし，これらの絶滅危惧種が土袞撒き出しにより発芽した ことが確認された。

\section{4. 考察}

土壤の深さが増すほど，水生植物の種数と個体数が減少すると

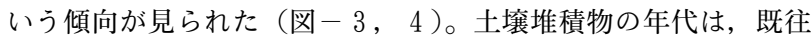
研究とほぼ一致する内容であった ${ }^{27)}$ 。横大路付近の粘土層の年代

ミス゚ワラビ
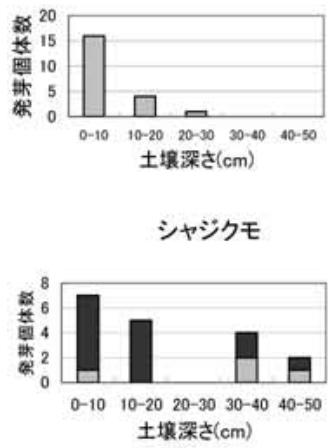

アメリカミズキンパイ

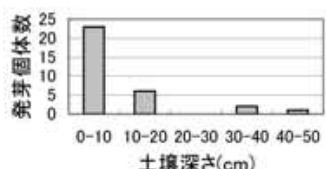

図－6 絶滅危惧種あるいは外来種の発芽した土壤の深さ
ミスマッハ
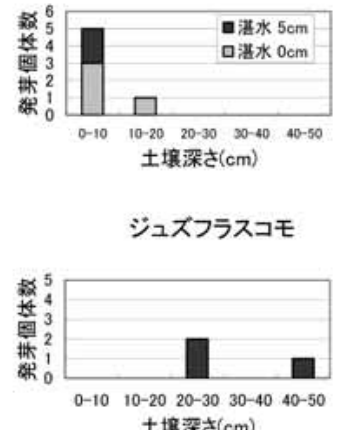

ホソパヒメミソハギ

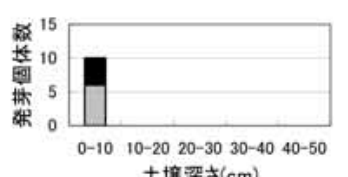

土墳深さ $(\mathrm{cm})$ 
測定によると，土壤深さと絶対 年代はほぼ比例関係にあること が示されており ${ }^{277}$, 図一 5 でわ かった土袞深さが大きくなると 個体数が指数関数的に減少する ことと合わせて考えると, 土㙵 シードバンク中の生存種子の量 は，時間経過とともに指数関数 的に減少するという知見が得ら れる。このことは既往文献28) と 一致している。

土壌深さが大きくなると生存 種子の数が減少する原因として

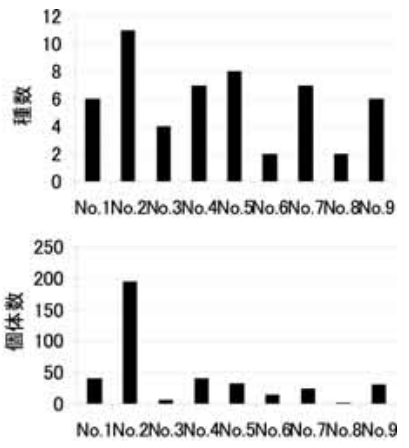
は，一般に，土壤深さが大きく なるほど堆積年は古くなり, 深い層の散布体ほど生存率が低くな ることと, 地表面からの散布体の供給が考えられる。これは, 土 壌採集地点の $5 \mathrm{~m}$ 以内で生育が確認されたミズワラビとミズマ ツバは, 現地で生育が確認されなかったシャジクモやジュズフラ スコモ, ミズアオイと異なり, 表層 $0-10 \mathrm{~cm}$ からの発芽が多かっ たことからも推察された（図一6）。

シャジクモやジュズフラスコモ等では, 深さ $40 \sim 50 \mathrm{~cm}$ の層 からも発芽が確認された (図一 6 )。放射性土壌堆積物の推定年 代は約 560 930 年前であった。これが直ちに散布体の生産され た年代であるとは限らない。土壌動物や植物の根の活動, 地震に よるひび割れ等の影響を受けて, 微小な散布体が土壌の深部に移 動したことが考えられる。車軸藻植物については, 数十年たった 散布体バンク（胞子バンク）により植生の回復の可能性があるこ とが報告されており ${ }^{29}$, 干拓後 50 年以上が経過した本研究の結 果之一致する。車軸藻植物は, 散布体が長寿命であり, 深さ 40 〜 $50 \mathrm{~cm}$ の土層からも発芽する可能性があると考えられる。

湛水条件については, 種により発芽に適した条件があること, 全体でみると $5 \mathrm{~cm}$ 区りも $0 \mathrm{~cm}$ 区の方が, 種数, 個体数ともに多 いことがわかった（表－2）。これは, Liu ら ${ }^{12)}$ の結果と一致し ていた。

土壌シードバンクを用いた植生復元を行う場合, 外来種の種子 を含まない土壤を用いることが望ましい ${ }^{28)}$ 。本研究においては, 土壌深さ $20 \sim 30 \mathrm{~cm}$ の土層において外来種の種子発芽が見出され なかった (図一-3) が, 土壌中の散布体バンクの分布は局所的で あるため,さらに検討が必要である。

\section{5.まとめ}

干拓後 50 年以上が経過した干拓地において, 土壌深さ $50 \mathrm{~cm}$ ま での土壌を採集し, 撒き出し実験を行った結果, 6 種の絶滅危惧 種の発芽が確認された。これらには, 現在生育が確認されていな いジュズフラスコモやミズアオイが含まれており, 土㙵中の散布 体バンクを利用した自然再生の有効性が示された。また, 土袞の 深さが増すほど, 発芽する水生植物の種数と個体数は指数関数的 に減少するという傾向が見られた。この原因としては, 散布体の 寿命と, 地表からの散布体の供給が考えられた。絶滅危惧種であ るシャジクモやジュズフラスコモは, 土壌深さ $40 \sim 50 \mathrm{~cm}$ の層か らも発芽することが明らかとなった。

巨椋池干拓地, 横大路沼干拓地に扔ける, 土壌シードバンクを 用いた植生復元の可能性が示唆された。しかし, 外来種の埋土種 子との混在があること, 季節的シードバンクを形成する種では植 生復元が困難であり永続的シードバンクを形成する種に限られる こと ${ }^{28)}$ な゙については，さらに検討が必要である。

\section{引用文献}

1 ）山崎明男（2006）：日本の干拓地:農林統計協会, $227 \mathrm{pp}$

2 ）滋賀県（2008）：早崎内湖再生計画案：滋賀県ホームページ $<\mathrm{ht}$ tp://www.pref.shiga.jp/d/biwako/hayasaki_naiko/hayasaki 01.htm>, 2008.9.1 参照

3 ）河北潟自然再生協議会（2002）：河北潟の自然再生構想：河北 潟自然再生協議会ホームページ http://sizensaisei.yupapa.net/, 2008.9.1 参照

4 ）百原新・上原浩一・藤木利之・田中法生（2001）：千葉県手賀 沼湖底堆積物中の埋土種子の分布之保存状態：筑波実験植物園 研究報告 $20,1-9$

5 ）亀山章 (2002）：生態工学：朝倉書店, $168 \mathrm{pp}$

6 ）佐合隆一（1995）：農耕地における埋土種子：雑草研究 40(4), $252-261$

7 ）嶺田拓也・沖陽子（1997）：雑草防除法, 耕起法および作付け 様式の異なる水田における埋土種子の比較 : 雑草研究 42(2), 81-87

8 ) 伊藤浩二・加藤和弘・高橋俊守 ・ 石坂健彦 ・藤原宣夫 (2003) : 河川氾濫原に扔ける土壤シードバンクの分布特性と水流の影響： ランドスケープ研究 66(5), 591-594

9 ) 荒川香織・亀山章（2006）：河川氾濫原の埋土種子の分布と発 芽特性：日本緑化工学会 32(1), 56-61

10）西廣淳・高川晋一，宮脇成生・安島美穂（2003）：霞ヶ浦岸域 の湖底土砂に含まれる沈水植物の散布体バンク：保全生態学研 究 8, 113-118

11) Bonis, A. and Lepart, J. (1994): Vertical structure of seed banks and the impact of depth of burial on recruitment in two temporary marshes: Vegetatio 112, 127-139

12) Liu, G., Zhou, J., Li, W. and Cheng Y. (2005): The seed bank in a subtropical freshwater marsh: implications for wetland restoration: Aquatic Botany 81, 1-11

13）巨椋池土地改良区（2001）：巨椋池干拓六十年史：巨椋池土地 改良区, $102 \mathrm{pp}$

14）佐和隆研（1984）：京都大事典：淡交社, $965 \mathrm{pp}$

15）三木茂（1927）：巨椋池の植物生態：京都府史跡名勝地調查会 報告 8, 81-145

16）国土交通省（2006）：近畿圈の都市環境インフラのグランドデ ザイン：環境省ホームページくhttp://www.mlit.go.jp/kisha/ki sha06/02/020809_html>, 2008.9.23 参照

17）角野康郎（1994）：日本水草図鑑：文一総合出版, $179 \mathrm{pp}$

18）佐竹義輔 - 大井次三郎 - 北村四郎 - 亘理俊次 - 冨成忠夫（1981） : 日本の野生植物 草本 III 合弁花類：平凡社 $259 \mathrm{pp}$

19）佐竹義輔 - 大井次三郎・北村四郎・亘理俊次・富成忠夫（1982） : 日本の野生植物 草本 I 単子葉類 : 平凡社 $305 \mathrm{pp}$

20）佐竹義輔 - 大井次三郎 - 北村四郎 - 亘理俊次 - 富成忠夫（1982） : 日本の野生植物 草本 II 離弁花類 : 平凡社 $318 \mathrm{pp}$

21）清水建美編（2003）：日本の帰化植物：平凡社 $337 \mathrm{pp}$

22）環境省（2007）：レッドデータブック：ホームページ<http:// www.rdbplants.jp/>, 2008.9.1.参照

23）レッドデータブック近畿研究会（2001）：改訂・近畿地方の保 護上重要な植物 レッドデータブック近畿 2001 : 平岡環境科学 研究所, $164 \mathrm{pp}$

24）京都府：京都府レッドデータブック：ホームページくhttp://ww w9.pref.kyoto.lg.jp/kankyo/rdb/index.html>,2008.9.16 参照

25）山根一郎（1982）：水田土袞学：農山漁村文化協会，347 pp

26）坂東忠司・谷川幸江・櫻井真由美（2001）：巨椋池干拓地（京 都）の植物相：京都教育大学環境教育研究年報 9,85-99

27）林屋辰三郎・藤岡謙二郎（1974）：宇治市史 2 ：宇治市役所, $577 \mathrm{pp}$

28）熟谷いづみ・草刈秀紀（2003）：自然再生事業一生物多様性の 回復をめざして : 築地書館, $371 \mathrm{pp}$

29) Bonis, A. and Grillas, P. (2002) : Deposition, germination and spatio-temporal patterns of charophyte propagule banks: a review: Aquatic Botany 72, 235-248 